\title{
THE NEED FOR A CALIBRATED RADIOCARBON CHRONOLOGY OF NEAR EASTERN ARCHAEOLOGY
}

\author{
H J BRUINS \\ Jacob Blaustein Institute for Desert Research, Ben-Gurion University \\ of the Negev, Sede Boqer Campus 84993, Israel \\ and \\ W G MOOK \\ Centre for Isotope Research, University of Groningen \\ Groningen, The Netherlands
}

\begin{abstract}
Progress in radiocarbon dating and calibration accuracy should lead to the development of a calibrated radiocarbon chronology of Near Eastern archaeology, particulary for historical times. The lack of such an independent and impartial chronology is a major constraint, not only in archaeological studies, but also for interdisciplinary research involving the history of man, landscape and climate in the Near East and adjacent regions.
\end{abstract}

\section{INTRODUCTION}

The so-called Three-Age system, a division of the human past into Stone, Bronze and Iron Ages, was first developed in the 18th and 19th centuries by Scandinavian historians and archaeologists. In 1819 the Danish National Museum became the first museum in the world to display its archaeological collection according to the Three-Age system (Daniel, 1967). Archaeologists still use this differentiation today, albeit in modified form with much more complex subdivisions.

The original concept of the Three-Age system denoted simple technological and industrial stages. However, with the further growth and development of archaeology, connotations of a different nature became attached to these terms, eg, cultural, functional, diffusionist, economic, chronological (Daniel, 1943, 1967). Braidwood (1946) remarked “... to assume that we have 'dated' Mount Carmel by calling it simply 'LevalloisoMousterien' is meaningless, as the latter is not a term with primarily chronological meaning." More than 40 years later, there is still much to be learned from this position. "Today we are still mixing up time units and archaeological entities" (Bar-Yosef, 1981).

Regional differences in the rate of technological progress, as well as the existence of contemporaneous cultural differences within even small areas, render the use of terms like "Late Bronze Age" rather meaningless in a chronological sense. The need to base chronology on actual dates and not on cultural periods was expressed by Atkinson (1956) as well as by Braidwood (1946).

\section{ABSOLUTE DATING WITH HISTORICAL CHRONOLOGIES}

Absolute dating in Near Eastern archaeology through historical chronologies is ultimately based on the quality and reliability of Egyptian, 
Mesopotamian and other historic calendars. The Egyptian Historical Calendar (Hayes, 1973; Krauss, 1985; Kitchen, 1987) is the main cornerstone for archaeological dating in many parts of the Near East, while the Mesopotamian Chronology (Brinkman, 1964, 1979/80; Rowton, 1970; Huber, 1982, 1987) also occupies a prominent position. The interpretation of ancient records has often led to differences of opinion among experts. Various interpretations are usually possible and the reliability of these ancient sources often cannot be answered (Henige, 1986). It is beyond the scope of this paper to review these chronologies, but a few remarks seem appropriate.

Egypt. The Egyptian chronology is not founded on a complete list of the Pharaohs and their regnal years, as such a canon has not been preserved, but on varied fragmentary sources, linked in an intricate web of interrelations (Save-Soderbergh \& Olsson, 1970; Krauss, 1985; Helck, 1987; Hornung, 1987; Kitchen, 1987). The Egyptian Calendar has been tied to real time on the basis of ancient astronomical observations. The earliest record of the heliacal rising of Sothis, identified with the star Sirius, is written on a papyrus fragment of a temple register from Lahun, a city built by Sesostris II during the Twelfth Dynasty (Middle Kingdom). "The date is Year 7, Month 8, Day 16 , probably in the reign of Sesostris III; astronomical calculation places the point between 1876 and 1864 BC, probably in 1872" (Finegan, 1986). However, taking Elephantine as a supposed observation point, Krauss (1985) assigns Year 7 to $1830 \mathrm{BC}$. Other data involving the heliacal rise of the Sothis star were recorded during the New Kingdom.

From these astronomically "fixed points," the Egyptian chronology has been extended backward and forward, reconstructed from figures on the Palermo Stone, the Turin Canon and other fragmentary records. However, the intermediate periods between the Old, Middle and New Kingdoms pose particular chronological problems. Bietak (1984) notes that the term "absolute" must be used with caution for the Egyptian Calendar, as intrepretations of the observations of the Sothis star vary. "Even the Middle Kingdom chronology is not as stable as we once thought it was" (Bietak, 1984). Differences of opinion usually range from several tens for the New Kingdom chronology up to ca 400 years for the beginning of the first Egyptian Dynasty (White, 1952; Helck, 1968; $c f$ Shaw, 1985).

Mesopotamia. Written sources in Mesopotamia have led to the establishment of an absolute historical chronology (Brinkman, 1964, 1979/80; Rowton, 1970; Huber, 1982, 1987). A "Dark Age", characterized by a scarcity in written documents, exists in the middle of the second millennium $\mathrm{BC}$, from about the end of the 17th century BC to the first quarter of the 14th century BC (Finegan, 1986; Nissen, 1987a). This dark age complicates the absolute fixation of still older historical chronologies, the Ur III - Old Babylonian periods and the whole 3rd millennium. However, more recent research by Huber $(1982,1987)$ has led to astronomical dating of Babylon I and Ur III, "Currently, there are three distinct sources of astronomical evidence that are of direct relevance for the absolute chronology of the late third and early second millennium $\mathrm{BC}$ : the Venus tablet data, month-lengths as recorded on contemporary economic texts, and a few lunar eclipse omina contained in tablets 20 and 21 of Enuma Anu Enlil" (Huber, 1987). Based 
on the astronomical evidence Huber (1987) concludes that the so-called long chronology is right, with Ammisaduqa's first year beginning in $1702 \mathrm{BC}$.

The absolute historical chronology of the oldest phases of Mesopotamian history is to some extent dependent on Egypt (Brinkman, 1979/80; Nissen, 1987b). The Sumerian King List presents a long sequence of local dynasties from before and after the flood with their rulers and their regnal years. Nissen (1987a) noted that for the "earlier periods the figures given are fantastically high and certainly reflect more mythical ideas than reality. The figures given for the rulers of the dynasty of Akkad are more within a realistic range, and thus could be real, though a figure for Sargon, the first ruler, of 56 years certainly is on the verge. However, since we have no other means of control we simply have to assume that these figures are correct."

Israel (Canaan, Palestine). Archaeological chronology and terminology in Israel (Canaan, Palestine) and its immediate surroundings during the Bronze Age and later periods have largely been determined by stratigraphy, ceramic sequences and datable foreign synchronisms. The history of this development, as well as the current situation and problems involved, has been put forward by Gitin (1985) in an important and elucidating article. The comparison of stratified ceramic sequences, including datable foreign synchronisms, with neighboring regions, particulary Egypt, but also with the Aegean, Cyprus, Asia Minor and Mesopotamia, led to the development of chronological classifications.

Findings of datable Egyptian objects in local context or local pottery found in datable Egyptian contexts have been of particular importance. The historical chronology of Egypt thus forms the main basis for the chronology of archaeological periods in the land of Israel (Canaan, Palestine) during the Bronze and Iron Ages, through a step-wise linkage involving the association of historical chronological data of a political nature with archaeological data. The historical chronology of Mesopotamia plays a smaller role in this respect.

Different viewpoints have arisen out of this development and, as a result, it is possible that different chronologies, terminologies and perceptions of history are often based on the same stratified data (Gitin, 1985). An elucidating example is the problem about the age of the early fortress and related agricultural settlement network in the Negev and Northeastern Sinai (Cohen, 1980). The ceramic complexes involved have been assigned to a variety of ages, as described by Cohen (1980): 10th-7th century BC (Aharoni, 1967); 10th century BC (Cohen, 1980, 1983); 11th century BC (Aharoni, 1976); 13th century ВС or before (Rothenberg, 1972).

The problem of association. In addition to the qualitative and quantitative uncertainties in the use of ancient chronologies for absolute dating, there is the crucial problem of association: how to link a historical chronology with archaeological data. Following the Scandinavian Three-Age system, archaeology in the Near East is often organized in periods based on material and cultural remains. The periodization of historical chronologies is, however, political in nature and not cultural. This poses dating problems for archaeological strata and remains which cannot be related to historical, political figures. Moreover, the organization of historical archaeological periods 
in Egypt is, unlike the neighboring regions, also based upon political historical data and less upon its cultural context. Bietak (1984) has noted that the correlation of Egyptian periods with neighboring cultures is an approach to historical chronology with insufficiently explored material linkage.

Limited applicability to environmental archaeology. The applicability of historical chronologies is even more restricted for dating environmental history, a crucial factor in understanding human history. In the study of ancient man-land relationships and paleoclimate in the desert regions of the Negev and Sinai during historical times (Bruins, 1986, 1987), widely different opinions about archaeological chronology based on historical dating have proved a handicap. There is an inherent danger that paleoclimatic conditions dated geochronologically might be erroneously related to historic-archaeological developments dated by pottery complexes of questionable age.

\section{ABSOLUTE DATING WITH RADIOCARBON}

Notwithstanding the unique nature and value of the historical chronologies in the Near East, unsolved problems remain (Henige, 1986), while their application is limited. Thus, it makes a lot of sense to employ chronometric measurements of a completely different nature to evaluate, test and, if necessary and possible, correct historical and archaeological chronologies. Radiocarbon dating, a widely applicable standard dating method, should be used in archaeological excavations, in addition to archaeo-historical age assessments. "Radiocarbon dating has the advantage of being dependent only on the physical properties of the earth, and thus being equally and directly applicable on all parts of the earth, without the cumbersome step-wise transfers that are inherent to historical dating" (Waterbolk, 1987).

Upon the discovery of radiocarbon dating and its first use in 1950, Libby (1955) tested the validity of his new method though comparison with the Egyptian Historical Calendar, using archaeological material from ancient Egypt. With vastly improved dating precision (smaller standard deviations) and accuracy (dendrochronological calibration) of ${ }^{14} \mathrm{C}$ in recent years, Hassan and Robinson (1987) state that the reverse process has begun, "verifying and correcting the conventional chronology for Egypt and neighboring regions by calibrated radiocarbon."

The eventual development of an independent calibrated radiocarbon chronology of Near Eastern archaeology is necessary and will be the natural outcome of current progress in ${ }^{14} \mathrm{C}$ dating. Having addressed some of the problems and limitations of historical dating, it is only fair to mention, besides its assets, also the problems of ${ }^{14} \mathrm{C}$ dating.

Standard deviations. Unlike dating with historical chronologies, by which the probability of the result cannot usually be ascertained mathematically, the ${ }^{14} \mathrm{C}$ result is expressed as a central date of highest probability with a certain standard deviation. The statistical uncertainty of this probability has been narrowed considerably since the discovery of ${ }^{14} \mathrm{C}$ dating, from several hundred years to a few decades. Standard deviations $(1 \sigma)$ of $25-50$ years for

${ }^{14} \mathrm{C}$ dates are possible on a routine basis and virtual point dates $( \pm 10 \mathrm{yr})$ can be produced if enough sample and proper equipment are available (Mook 
\& Waterbolk, 1986; Mook, Hasper \& van der Plicht, 1987).

Calibration, though vital for higher accuracy in real time, has complicated the numerical expression of a ${ }^{14} \mathrm{C}$ date in a uniform and statistically precise sense. In time areas where the calibration curve has a steep inclination, the standard deviation of the calibrated date may become smaller than the precalibrated date in conventional ${ }^{14} \mathrm{C}$ years. In time areas with a more horizontal or irregular calibration curve the opposite occurs, widening the probability range of the ${ }^{14} \mathrm{C}$ date. The smaller the standard deviation of the ${ }^{14} \mathrm{C}$ date before calibration, the better the prospects for precise dates with a small standard deviation after calibration.

$A M S$. Another important breakthrough in ${ }^{14} \mathrm{C}$ dating in recent years has been the development of Accelerator Mass Spectrometry (AMS), which is able to date milligram-size samples. AMS does not measure the activity of ${ }^{14} \mathrm{C}$ but determines its isotopic concentration. This method has opened up new horizons for ${ }^{14} \mathrm{C}$ dating in an archaeological context. Since only a very small sample is required, many more stratigraphic layers may yield sufficient material for dating. Tiny remnants of charcoal adhering to pottery, or charred grains inside sherds can be dated. Precious documents and rare archaeological objects may now be dated without destroying them.

Calibration of ${ }^{14} \mathrm{C}$ dates into real time. Besides the improved physical measurement of ${ }^{14} \mathrm{C}$, another crucial development, particularly important for historical archaeology, has been the establishment of high-precision calibration curves from tree-ring dates. The ${ }^{14} \mathrm{C}$ concentration in the atmosphere has not been constant through time (de Vries, 1958; Suess, 1970; Damon, 1987). An uncalibrated ${ }^{14} \mathrm{C}$ date, therefore, is expressed in conventional ${ }^{14} \mathrm{C}$ years, not in REAL astronomical years. The difference may be many hundreds of years. Measurement of the ${ }^{14} \mathrm{C}$ activity in tree-ring series of known age has enabled the determination of past variations in atmospheric ${ }^{14} \mathrm{C}$ content. High-precision calibration curves have been developed as a result, which enable the translation of a ${ }^{14} \mathrm{C}$ date from conventional ${ }^{14} \mathrm{C}$ years (BP) into REAL historical years ( $\mathrm{cal} \mathrm{AD} / \mathrm{BC}$ ) for the time spans covered by reliable treering series. The calibration curves of Stuiver and Pearson (1986) and Pearson and Stuiver (1986) have been recommended by international convention (Stuiver \& Kra, 1986) for the period from 2500 BC until the present.

Calibration procedures. Proper calibration of ${ }^{14} \mathrm{C}$ dates is very important in the development of $\mathrm{a}^{14} \mathrm{C}$ chronology of Near Eastern archaeology. Calibration involves the following steps:

1) Physical measurement of ${ }^{14} \mathrm{C}$ date in conventional ${ }^{14} \mathrm{C}$ years $\mathrm{BP}$, with as high a degree of precision as possible.

2) Computerized calibration of the ${ }^{14} \mathrm{C}$ date (van der Plicht, Mook \& Hasper, 1987; van der Plicht \& Mook, 1988), from a Gaussian probability distribution with standard deviation around a central date BP via the calibration curve into a graphic picture of the calibrated probability distribution (cal $\mathrm{AD} / \mathrm{BC})$.

3) Numerical expression ( $\mathrm{cal} \mathrm{AD} / \mathrm{BC}$ ) of the graphic result.

Whereas step 1 has been internationally standardized (although there may be large individual differences in the quality of a ${ }^{14} \mathrm{C}$ date due to sample amount, material, time-width, archaeological association, equipment etc), 
steps 2 and 3 are still in progress. The inherent problems are:

1) There is not yet a "final" calibration curve based on single-year tree rings.

2) The shape of the calibration curve has to be adapted to the timewidth of the dated sample to be calibrated (Mook, 1983; Mook, Hasper \& van der Plicht 1987).

3) The irregular shape of the calibration curve (due to variations of the ${ }^{14} \mathrm{C}$ content in the atmosphere through time) causes the calibrated ${ }^{14} \mathrm{C}$ date to have a complex non-Gaussian probability distribution, which is difficult to express numerically.

International guidelines should be developed for a "best possible" interpretation and numerical expression in a statistically precise sense of the graphic calibration result. A concensus should be reached on a standard calibration procedure (Mook, Hasper \& van der Plicht, 1987).

\section{THE ESTABLISHMENT OF A CALIBRATED RADIOCARBON CHRONOLOGY} OF NEAR EASTERN ARCHAEOLOGY

In their article on ${ }^{14} \mathrm{C}$ dating of Palestine in the Early Bronze Age, Callaway and Weinstein (1977), stated, "an increasing number of radiocarbon dates has become available in recent years, presenting us with the potential for an absolute chronology independent of foreign synchronisms." Weinstein (1984) published a very useful list of $474{ }^{14} \mathrm{C}$ dates from the Southern Levant arranged according to archaeological periods. Waterbolk (1987) evaluated these dates in various group analyses, showing interesting regularities but also deviations and quality differences. Hassan and Robinson (1987) published an important chronometric listing and evaluation of ${ }^{14} \mathrm{C}$ dates of ancient Egypt, compared to neighboring regions. However, many more samples from ancient Egypt ought to be investigated, as urged in 1969 at the Twelfth Nobel Symposium (Olsson, 1970) where a resolution was adopted expressing the importance "to collect more samples from Egypt systematically... samples should then be distributed between the participating laboratories and institutes for analysis, combined with inter-laboratory checks."

In line with the above resolution, Haas et al (1987) made an exemplary analysis of Egyptian material from the Old Kingdom in which they collected 80 samples from important pyramids and associated monuments of the 3rd - 6th Dynasties. The collection and documentation of the samples, carefully planned in advance, was carried out in one period (February, 1984) by the same scholars, Lehner and Wenke (see Haas et al, 1987). The material consisted of 43 samples of organic inclusions in the gypsum mortar between stone blocks of pyramids and 37 "combined" samples of carbonized and uncarbonized materials fom several locations, ranging from wood beams projecting from the core of Djoser's Step Pyramid at Saqqara to unburned reeds from mudbrick walls incorporated in pyramid complexes. Small samples were dated by AMS at the ETH laboratory in Zurich and the larger samples with benzene synthesis liquid scintillation counting at the SMU laboratory in Dallas. Interlaboratory tests were performed and the ${ }^{14} \mathrm{C}$ dates were 
calibrated according to S W Robinson (ms in preparation). The result of the well-planned research was striking: calibrated ${ }^{14} \mathrm{C}$ dates of samples from the 3rd - 6th Dynasties are, on average, 374 years older than the ancient Egyptian calendar dates according to the Cambridge Ancient History chronology (Hayes, 1973), used by the authors for comparison (Haas et al, 1987).

These results have aroused much controversy. One of the anonymous reviewers of the present paper remarked that the results are exceedingly debatable and stressed that replications by other ${ }^{14} \mathrm{C}$ laboratories of the dates by Haas et al (1987) are required before Egyptologists will take this new high chronology seriously. Hassan and Robinson (1987) noted that the results by Haas and Wölfli (1986; Haas et al, 1987) are not consistent with other ${ }^{14} \mathrm{C}$ dates from Egypt. They suspect that old wood and old organic debris may have influenced the results, a possibility which has to be investigated. However, they also note, "The existing corpus of radiocarbon measurements for ancient Egypt is, with a few exceptions, not fully satisfactory... And one should not rule out the possibility that the historical chronology and supporting radiocarbon dates are all too young" (Hassan \& Robertson, 1987).

It is clear that in the development of a calibrated ${ }^{14} \mathrm{C}$ chronology of Near Eastern archaeology, all regional ${ }^{14} \mathrm{C}$ dates have to be gathered in a computerized data base. An important cornerstone in this respect could be the formation of the International Radiocarbon Data Base (IRDB) (Kra, 1988a,b, 1989; Walker \& Kra, 1988). The compilation and screening of the radiocarbon dates require a thorough realization of the problems of ${ }^{4} \mathrm{C}$ dating (Mook \& Streurman, 1983; Waterbolk, 1987; Mook, Hasper \& van der Plicht, 1987). Some important criteria in the evaluation of ${ }^{14} \mathrm{C}$ dates have been outlined by Waterbolk (1983a,b, 1987). It is extremely important to assess the certainty by which a ${ }^{14} \mathrm{C}$ sample can be associated with an archaeological event or period. Moreover, an assessment should be made to what extent the organic material for ${ }^{14} \mathrm{C}$ dating may be older than its associated archaeological context. The botanical or faunal nature of the sample should be identified microscopically, if necessary, and examined for possible contamintion.

The basic requirements to develop a calibrated radiocarbon chronology of Near Eastern archaeology may be summarized as follows:

1) The formation of a data base of all available ${ }^{14} \mathrm{C}$ dates for the region, with continuous updating. This might be accomplished in the framework of the pilot project "Paleoenvironment and Human History in the Southeast Mediterranean" of the IRDB, as proposed by Kra (1988b).

2) The production of internally consistent series of precise ${ }^{14} \mathrm{C}$ dates from carefully selected archaeological sites, strata and artifacts.

3) Evaluation of each ${ }^{14} \mathrm{C}$ date: sample material, time range of sample, archaeological association, standard deviation.

4) Calibration according to internationally agreed guidelines, with graphic and numerical expression of the result.

5) Chronological ordering of the ${ }^{14} \mathrm{C}$ dates according to area, age and association with archaeological and historical periods. 


\section{CONCLUSIONS}

The use of historical chronologies to determine absolute ages in Near Eastern archaeology is not without problems. The difficulties and limitations are basically fourfold: 1) reliability of ancient chronologies, 2) fixing ancient chronologies to real time, 3 ) relating historical chronologies to excavated archaeological strata, buildings or artifacts, 4) restricted application of ancient chronologies to environmental history.

${ }^{14} \mathrm{C}$ dating is independent of historical dating and may, therefore, be used legitimately in the verification and possible correction of ancient historical chronologies, provided resolution and accuracy are sufficiently precise. Calibrated ${ }^{14} \mathrm{C}$ data may also enable linkages, if not possible otherwise, of historical chronologies with archaeological strata, artifacts and environmental history, as time is the ultimate basis of stratigraphy. High-precision ${ }^{14} \mathrm{C}$ dating will form the basis for the development of a calibrated ${ }^{14} \mathrm{C}$ chronology of Near Eastern archaeology. It is necessary to obtain carefully selected series of scores or even hundreds of new high-precision ${ }^{14} \mathrm{C}$ dates. Research in the Southern Levant is still in progress (Bruins, 1986; Bruins \& Mook, 1987; Weinstein, ms in preparation). The establishment of the International Radiocarbon Data Base, as proposed by Kra (1988a,b, 1989), could be a helpful mechanism to compile and organize the data. It would be ideal to have a calibration curve based on single-year tree rings. An international concensus should be reached on a standard calibration procedure and expression of the result.

Both historical and ${ }^{14} \mathrm{C}$ dating have their own unique assets and limitations. A "scholarly" attituđe towards ${ }^{14} \mathrm{C}$ dating as a mere indication of probability not to be taken seriously, is as unhelpful in the search of past reality as "scientific" derision of archaeo-historical dating as merely subjective interpretation of layers and antiquities with no semblance of probability. Together, and in tune with each other, they constitute a comprehensive approach to the archaeo-historic past, by which some of the outstanding chronological controversies might be resolved. A concerted effort should be made to establish a calibrated ${ }^{14} \mathrm{C}$ chronology of Near Eastern archaeology, particularly for the so-called Bronze and Iron Ages.

\section{ACKNOWLEDGMENTS}

The comments on an early version of this manuscript by Prof David Faiman and two anonymous reviewers were very much appreciated, and have been taken into account.

\section{REFERENCES}

Aharoni, Y, 1967, Forerunners of the Limes: Iron Age fortresses in the Negev: Israel Exploration Jour, v 17, p 1-17. 1976, Nothing early and nothing late: Biblical Archeologist, v 39, p 55-76. Atkinson, R J C, 1956, Stonehenge: London, Hamilton.

Bar-Yosef, O, 1981, The "Pre Pottery Neolithic" period in the Southern Levant, in Prehistoire du Levant, Colloques Internationaux du CNRS, no. 598: Lyon, Maison de 1 Órient, p 555569.

Bietak, M, 1984, Problems of Middle Bronze Age chronology: New evidence from Egypt: Am Jour Archaeol, v 88, p 471-485.

Braidwood, R J, 1946, Terminology in prehistory, human origins, an introductory general 
course in anthropology, Selected reading ser II: Chicago, Univ Chicago Press, p 32-45.

Brinkman, J A, 1964, Mesopotamian chronology of the historical period, App, in Oppenheim, A L, Ancient Mesopotamia, Portrait of a dead civilization: Chicago, Univ Chicago Press, p 335-348.

1979/80, Chronologies of the Near East, 3500-2000 BC: The sixtieth anniversary symposium of the Oriental Institute: Oriental Inst Ann rept, p 55-62.

Bruins, H J, 1986, Desert environment and agriculture in the central Negev and Kadesh-Barnea during historical times: Nijkerk, The Netherlands, Midbar Foundation, $219 \mathrm{p}$

in press, Ancient agriculture in the Negev, in Oren, E and Gilead, I, eds, Archaeological congress in Israel, 13th, Proc: Beersheva, Ben-Gurion Univ.

Bruins, H J and Mook, W G, in press, Radiocarbon dating in the Northeastern Sinai desert (Ein el Gudeirat, Kadesh-Barnea), in Waterbolk, HT and Mook, W G, eds, Internatl symposium, Archaeology and ${ }^{14} \mathrm{C}$, 2nd, Proc: PACT.

Callaway, J A and Weinstein, J M, 1977, Radiocarbon dating of Palestine in the Early Bronze Age: Bull Am Schools Oriental Research, v 225, p 1-16.

Cohen, R, 1980, The Iron Age fortresses in the Central Negev: Bull Am Schools of Oriental Research, v 236, p 61-79.

1983, Kadesh-Barnea, A fortress from the time of the Judean Kingdom: Jerusalem, The Israel Mus.

Damon, P E, 1987, The history of the calibration of radiocarbon dates by dendrochronology, in Aurenche, O, Evin, J and Hours, F, eds, Chronologies in the Near East: Oxford, BAR Internatl ser, p 61-104.

Daniel, G, 1943, The three ages: Cambridge, Cambridge Univ Press. Ltd, 304 p.

1967, The origins and growth of archaeology: Harmondsworth, Penguin Books

Finegan, J, 1986, Archaeological history of the ancient Middle East: New York, Dorset Press, $456 \mathrm{p}$.

Gitin, S, 1985, Stratigraphy and its application to chronology and terminology, in Biblical archaeology today, Internatl cong on biblical archaeology, Proc: Jerusalem, Israel Exploration Soc, p 99-107.

Haas, H, Devine, J M, Wenke, R, Lehner, M, Wölfli, W and Bonani, G, 1987, Radiocarbon chronology and the historical calender in Egypt, in Aurenche, O, Evin, J and Hours, F, eds, Chronologies in the Near East: Oxford, BAR Internatl ser, p 585-606.

Haas, H and Wölfli, W, 1986, Extension of the data base for Egyptian chronology, Abs: Soc Am Archaeol, ann mtg, 51st, New Orleans.

Hassan, F A and Robinson, S W, 1987, High-precision radiocarbon chronometry of ancient Egypt, and comparisons with Nubia, Palestine and Mesopotamia: Antiquity, v 61, p 119 135 .

Hayes, W C, 1973, Chronology: Egypt to the end of the Twentieth Dynasty, in Edwards, IES, Gadd, C J, and Hammond, NGL, eds, Cambridge Ancient History, 3rd ed, vol 1, pt 1: Cambridge, Cambridge Univ Press, p 173-193.

Helck, W, 1968, Geschichte des Alten Ägypten, in Spuler, B, ed, Handbuch der Orientalistik, Erste Abt, vol 1, pt 3: Leiden and Cologne, p 24-44.

1987, Was Kann die Ägyptologie wirklich zum Problem der absoluten Chronologie in der Bronzezeit beitragen? Chronologische Annäherungswerte in der 18 Dynastie, in Åström, P, ed, High, Middle or Low? Internatl colloquium on absolute chronology, Proc: Univ Gothenburg, Sweden, Partille, Paul Åström, pt 1, p 18-26

Henige, D, 1986, Comparative chronology and the Ancient Near East: A case for symbiosis: Bull Am Schools Oriental Research, v 261, p 57-68.

Hornung, E, 1987, Lang oder Kurz? - das Mittlere und Neue Reich Ägyptens als Prüfstein, in Åström, P, ed, High, Middle or Low? Internatl colloquium on absolute chronology, Proc: Univ Gothenburg, Sweden, Partille, Paul Åströms, pt 1, p 27-36.

Huber, P J, 1982, Astronomical dating of Babylon I and Ur III: Malibu, California, Undena Pubs, Occasional papers on the Near East, v 1, no. 4, 93" p.

1987, Astronomical evidence for the Long against the Middle and Short chronologies, in Aström, P, ed, High, Middle or Low? Internatl colloquium on absolute chronology, Proc: Univ Gothenburg, Sweden, Partille, Paul Aströms, pt 1, p 5-17.

Kitchen, K A, 1987, The basics of Egyptian chronology in relation to the Bronze Age, in Åström, P, ed, High, Middle or Low? Internatl colloquium on absolute chronology, Proc: Univ Gothenburg, Sweden, Partille, Paul Åströms, pt 1, p 37-55. 
Kra, R S, 1988a, Updating the past: The establishment of the International Radiocarbon Data Base: Am Antiquity, v 53, p 118-125.

1988b, The first American Workshop on the International Radiocarbon Data Base: Radiocarbon, v 30, no. 2, p 259-260.

1989, The International Radiocarbon Data Base: A progress report: Radiocarbon, this issue.

Krauss, R, 1985, Sothis-und Monddaten, Studien zur astronomischen und technischen Chronologie Altägyptens: Hildesheim, Gerstenberger Verlag, Hildesheimer Ägyptologische Beitrage, 20.

Libby, W F, 1955, Radiocarbon dating: Chicago, Univ Chicago Press.

Mook, W G, $1983,{ }^{14} \mathrm{C}$ calibration and the time-width of ${ }^{14} \mathrm{C}$ samples, in Mook, W G and Waterbolk, HT, eds, Internatl conf on ${ }^{14} \mathrm{C}$ and archaeology, 1st, Proc: Strasbourg, PACT, v 8, p 517-525.

Mook, W G, Hasper, $\mathrm{H}$ and van der Plicht, J, 1987, Background and procedures of ${ }^{14} \mathrm{C}$ calibration, in Aurenche, O, Evin, J and Hours, F, eds, Chronologies in the Near East: Oxford, BAR Internatl ser, p 145-150.

Mook, W G and Streurman, H J, 1983, Physical and chemical aspects of radiocarbon dating, in Mook, W G and Waterbolk, H T, eds, Internatl conf on ${ }^{14} \mathrm{C}$ and archaeology, 1st, Proc: Strasbourg, PACT, v 8, p 31-55.

Mook, W G and Waterbolk, H T, 1985, Handbook for archaeologists, No. 3, radiocarbon dating: Strasbourg, European Sci Foundation.

Nissen, H J, 1987a, The chronology of the Proto- and Early Historic periods in Mesopotamia and Susiana, in Aurenche, $\mathrm{O}$, Evin, $\mathrm{J}$ and Hours, F, eds, Chronologies in the Near East: Oxford, BAR Internatl ser, p 607-614.

1987b, Introduction and summary of the session: La chronologie de 6000 a 4000 $\mathrm{BP}$, in Aurenche, $\mathrm{O}$, Evin, $\mathrm{J}$ and Hours, F, eds, Chronologies in the Near East: Oxford, BAR Internatl ser, p 679-680.

Olsson, I U, ed, 1970, Radiocarbon variations and absolute chronology, Nobel symposium, 12th, Proc: Stockholm, Almqvist \& Wiksell.

Pearson, G W and Stuiver, M, 1986, High-precision calibration of the radiocarbon time scale, 500-2500 BC, in Stuiver, M and Kra, R S, eds, Internatl ${ }^{14} \mathrm{C}$ conf, 12th, Proc: Radiocarbon, v 28, no. 2B, p 839-862.

Rothenberg, B, 1972, Timna: London, Thames and Hudson.

Rowton, M B, 1970, Chronology: Ancient western Asia: Cambridge, Cambridge Ancient His-

tory.
Säve-Söderbergh, T and Olsśon, I U, 1970, ${ }^{14} \mathrm{C}$ dating and Egyptian chronology, in Olsson, I $\mathrm{U}$, ed, Radiocarbon variations and absolute chronology, Nobel symposium, 12th, Proc: Stockholm, Almqvist \& Wiksell, p.35-55.

Shaw, I ME ies, v 44, p 295-317.

Stuiver, M and Kra, R S, eds 1986 , Internatl ${ }^{14} \mathrm{C}$ conf, 12 th, Proc: Radiocarbon, v 28, nos. $2 \mathrm{~A}$ and $2 \mathrm{~B}, \mathrm{p}$ 175-1030.

Stuiver, M and Pearson, G W, 1986, High-precision calibration of the radiocarbon time scale, AD 1950-500 BC, in Stuiver; Mand Kra, R S, eds, Internatl ${ }^{14} \mathrm{C}$ conf 12 th, Proc: Radiocarbon, v 28 , no. $2 \mathrm{~B}, \mathrm{p} 805-838$.

Suess, $\mathrm{H}$ E, 1970 , $\mathrm{Btintlecone}$ pine calibration of the radiocarbon time scale $5200 \mathrm{BC}$ to the present, in Olsson, I U, ed, Nobel symposium, 12th, Proc: Stockholm, Almqvist \& Wiksell, p 303-311.

van der Plicht, J and Mook, W G, 1988, Calibration of radiocarbon ages by computer: Radiocarbon, this issue.

van der Plicht, J, Mook, W G and Hasper, H, in press, An automatic calibration program for radiocarbon dating, in Waterbolk, HT and Mook, W G, eds, Internatl symposium on archaeology and ${ }^{14} \mathrm{C}$, 2nd, Proc: PACT.

Vries, H de, 1958, Variation in concentration of radiocarbon with time and location on earth: Koninkl Nederlandse Acad Wetenschappen, Proc: Ser B, v 61, p 94-102.

Walker, A J and Kra, R, 1988, Report on the International Radiocarbon Dața Base (IRDB) Workshop, Archaeology and ${ }^{14} \mathrm{C}$ conference, Groningen, The Netherlands: Radiocarbon, v 30, no. 2, p 255-258.

Waterbolk, H T, 1983a, Thirty years of radiocarbon dating; the retrospective view of a Groningen archaeologist, in Mook, W G and Waterbolk, H T, eds, Internatl conf on ${ }^{14} \mathrm{C}$ and archaeology, 1st, Proc: Strasbourg, PACT, v 8, p 17-27. 
1983b, Ten guidelines for the archaeological interpretation of radiocarbon dates, in Mook, W G and Waterbolk, H T, eds, Internatl conf on ${ }^{14} \mathrm{C}$ and archaeology, 1st, Proc: Strasbourg, PACT, v 8, p 57-70.

1987, Working with radiocarbon dates in southwestern Asia, in Aurenche, O, Evin, J and Hours, F, eds, Chronologies in the Near East: Oxford, BAR Internatl ser
p 39-59.

Weinstein, J M, 1984, Radiocarbon dating in the Southern Levant: Radiocarbon, v 26, no. 3 , p 297-366.

White, JEM, 1952, Ancient Egypt: London. 